\title{
Growth of Capsicum chinense Jacq. subjected to different irrigation depths in the northeastern region of Pará, Brazil
}

\section{Produção de Capsicum chinense Jacq. submetida a diferentes lâminas de irrigação na região nordeste do Pará, Brasil}

\author{
Valdeides Marques LIMA ${ }^{1}$; Joaquim Alves de LIMA JUNIOR²; Helane Cristina Aguiar SANTOS ${ }^{3}$; \\ André Luiz Pereira da SILVA ${ }^{4}$; Pedro Daniel de OLIVEIRA ${ }^{5}$; José Félix de BRITO NETO ${ }^{6}$
}

\begin{abstract}
${ }^{1}$ Mestre em Agronomia pela Universidade Federal Rural da Amazônia - UFRA, e-mail: valdeidesmarqueslima@hotmail.com
${ }^{2}$ Doutor em Engenharia Agrícola pela Universidade Federal de Lavras - UFLA, e-mail: joaquim.junior@ufra.edu.br

${ }^{3}$ Autor para Correspondência: Mestranda em Agronomia pela Universidade Federal Rural da Amazônia - UFRA, Av. perimetral, 2501 - Terra Firme, Belém - PA, 66077-830, Tel. (91) 3210-5165, e-mail: aguiar.helane@gmail.com

${ }^{4}$ Doutor em Agronomia (Ciência do Solo) pela Universidade Estadual Paulista Júlio de Mesquita Filho - UNESP, e-mail: andreengagronomo@gmail.com

${ }^{5}$ Doutor em Agronomia pela Universidade Federal Rural da Amazônia - UFRA, e-mail: Daniel.oliveira@ufra.edu.br

${ }^{6}$ Doutor em Agronomia (Agricultura) pela Universidade Estadual Paulista Júlio de Mesquita Filho - UNESP, e-mail: jose.felix@ccaa.uepb.edu.br
\end{abstract}

Recebido em: 17-05-2017; Aceito em: 24-08-2017

\begin{abstract}
Capsicum chinense Jacq. presents great prominence in the cuisine of Pará. This crop was cultivated with low technological level in its production chain, however, in the last years, there has been an increase in the size of the planted area, in view of the national and international recognition of the vegetable as a substitute for pepper. The objective of this work was to evaluate the effect of different irrigation depths on the yield of Capsicum chinense Jacq. cv. Lupita. The experiment was carried out at the Experimental Farm of the Federal Rural University of Amazonia (UFRA), located in the municipality of Igarapé-Açu-PA. The experimental design was a randomized block with five treatments and four replications. The treatments corresponded to five irrigation depths based on the evaporation of the Class ' $A$ ' pan (ECA) $(30,60,90,120$ and $150 \% E C A)$. The results showed that the maximum commercial yield was $14.0 \mathrm{tha}^{-1}$, reached at $101 \% \mathrm{ECA}$, which corresponds to a $724.50 \mathrm{~mm}$ depth, and the highest water use efficiency $\left(22.78 \mathrm{~kg} \mathrm{ha}^{-1} \mathrm{~mm}^{-1}\right)$ was obtained with the $458.64 \mathrm{~mm}$ total water depth at $56 \%$ ECA.
\end{abstract}

Additional keywords: class 'A' pan; irrigation management; water use efficiency.

\section{Resumo}

A Capsicum chinense Jacq. apresenta-se com grande destaque na culinária paraense. Esta cultura era cultivada com baixo nível tecnológico em sua cadeia de produção; no entanto, nos últimos anos, houve um incremento no tamanho da área plantada diante do reconhecimento nacional e internacional da hortaliça como substituta do pimentão. $O$ trabalho tem o objetivo de avaliar o efeito de diferentes lâminas de irrigação no rendimento da Capsicum chinense Jacq. cv. Lupita. O experimento foi realizado na Fazenda Experimental da Universidade Federal Rural da Amazônia (UFRA), localizada no município de Igarapé-Açu-PA. O delineamento experimental foi o em blocos casualizados, com cinco tratamentos e quatro repetições. Os tratamentos corresponderam a cinco lâminas de irrigação baseadas na evaporação do Tanque Classe "A" (ECA) (30; 60; 90; 120 e 150\% da ECA). Os resultados permitiram concluir que a produtividade máxima comercial foi de $14,0 \mathrm{t} \mathrm{ha}^{-1}$ atingida aos $101 \%$ da ECA, o qual corresponde a uma lâmina de $724,50 \mathrm{~mm}$ e a maior eficiência do uso da água $\left(22,78 \mathrm{~kg} \mathrm{ha}^{-1} \mathrm{~mm}^{-1}\right)$ com a lâmina total aplicada de $458,64 \mathrm{~mm}$ a $56 \%$ de reposição da ECA.

Palavras-chave adicionais: eficiência do uso da água; manejo da irrigação; tanque classe "A".

\section{Introduction}

The pepper (Capsicum chinense Jacq.) cv. Lupita, also known in Brazil as "pimentinha verde", is part of the group of sweet peppers. The fruits of this species present an annular constriction, allowing easy differentiation from other species with a high degree of genetic proximity. The center of greater diversity of this species is located in the Amazon Basin and the first cultivations were performed by the local Indians. Currently, this crop is grown on a larger scale in small areas by family farmers (Reifschneider \& Ribeiro,
2008).

It is estimated that, annually, the area planted with peppers in Brazil comprises five thousand hectares, allowing a production of 75 tons. The growing demand of consumer markets (internal and external) has provided an expressive increase in the area cultivated with sweet and chilli peppers, and the establishment of agro-industries in several Brazilian regions (Moura et al., 2013).

Pepper is a vegetable sensitive to water deficit. This sensitivity is manifested more expressively 
in the flowering and fruiting stage, with both the quantity and the quality of the fruits being affected (Doorenbos \& Kassam, 2000; Yaghi, Arslan \& Naoum, 2013). The effect of the water deficit on production has been studied by several authors under greenhouse and field conditions (Biblico et al., 2010; Ayas et al., 2011; Oliveira et al., 2011).

To ensure the most adequate use of water, it is necessary to consider the technical criteria established, such as: choice of irrigation system, water depth and time of application, which will allow greater productivity and, consequently, a better economic return. The drip irrigation system is the most recommended for the cultivation of pepper, since it tends to provide a water application with greater uniformity, fertigation efficiency, phytosanitary control, labor saving and better quality fruit production (Ribeiro et al., 2010; Qiu et al., 2011; Oliveira et al., 2011).

The north region has high rainfall, although it is not evenly distributed throughout the year, about $80 \%$ of rainfall is concentrated between January and July. The months of August to December are favorable to the use of the irrigation technique, highlighting the state of Pará (Sousa and Sousa, 2011).

Among the existing irrigation methods, Sousa et al. (2012) points out that $40.7 \%$ are classified as other methods and/or "wetting", which reinforces the importance of irrigation with a technology and management that meet the water needs and that can ensure a satisfactory crop yield. For Esteves et al. (2010), the use of irrigation demands a high volume of water, requiring the use of this technique in a rational way.

Given the expansion potential of the crop and the search for more technical information on the production system in the cultivation of pepper with the use of irrigation technology, this work aims to evaluate the effect of different irrigation depths with the use of Class 'A' pan (ECA) on the yield of pepper cv. Lupita.

\section{Material and methods}

The experiment was conducted in the field, from August 2014 to January 2015, at the Experimental Farm of the Federal Rural University of Amazonia (UFRA), with geographic coordinates $1^{\circ} 07^{\prime}$ 48.47" $\mathrm{S}$ and $47^{\circ} 36^{\prime}$ 45.31" $\mathrm{W}$ and altitude of $54 \mathrm{~m}$, in the municipality of Igarapé-Açu, northeast of Pará. The soil is classified as a Dystrophic Yellow Argisol of medium sandy texture (Souza et al., 2011). The climate of the region is type Ami, according to the Köppen classification, hot and humid, with average annual temperatures of 25 to $32^{\circ} \mathrm{C}$ and annual rainfall of $2500 \mathrm{~mm}$ to $3000 \mathrm{~mm}$, with uneven distribution and the existence of two to three months with drought.

The climatic data of the experiment period were recorded using a portable automatic weather station (Vantage Pro2, Davis), installed in the experimental area. The evaporation data were collected by means of a class A tank with internal diameter of 121 $\mathrm{cm}$ and height of $25.4 \mathrm{~cm}$. To measure the evaporation, a specially graded ruler in $\mathrm{cm}$ with resolution in $\mathrm{mm}$ was placed slopingly. Data collection and possible water replenishment in the Class ' $A$ ' pan were performed every two days at 7:30 am. The water level was kept at a maximum of $5 \mathrm{~cm}$ and at least $7.5 \mathrm{~cm}$ from the upper edge of the pan.

The cv. Lupita, used in this study, has a 120 -day cycle, characterized by vigorous plants with light green foliage, with sweet and quite aromatic fruits. The seedlings were produced in 15-cell trays, being sown on August 16, 2014 and taken to the field at 34 days after sowing (DAS), based on the information provided by the seed supplier.

The experimental design was a complete randomized block (CRB), with four replications. The treatments were constituted by irrigation depths equivalent to five percent of the water evaporated from the Class ' $A$ ' pan (ECA), corresponding to $30 \%, 60 \%$, $90 \%, 120 \%$ and $150 \%$ ECA (T30, T60, T90, T120 and T150, respectively), applied based on a two-day irrigation frequency. The experimental plots had dimensions of $4.00 \times 2.40 \mathrm{~m}$, with 10 plants spaced $1.2 \times 0.80 \mathrm{~m}$ apart, of which only the six central plants were used for the analysis of the experiment.

The soil of the experimental area was prepared by plowing and leveling at 90 days before transplanting the seedlings, soon after liming, with the application of $1.5 \mathrm{t} \mathrm{ha}^{-1}$ limestone to correct the soil acidity and raise the base saturation (V) to $80 \%$. Liming and planting and cover fertilization were performed manually based on the physical and chemical analysis of soil (Table 1).

Table 1 - Results of physical and chemical soil analysis of the experimental area. (1)

\begin{tabular}{|c|c|c|c|c|c|c|c|c|c|c|}
\hline \multirow{2}{*}{ Depth } & \multicolumn{10}{|c|}{ Attributes } \\
\hline & $\mathrm{pH}$ & $\mathrm{N}$ & O.M. & $P$ & $\mathrm{~K}$ & $\mathrm{Na}$ & $\mathrm{Ca}$ & $\mathrm{Ca}+\mathrm{Mg}$ & Al & $\mathrm{H}+\mathrm{Al}$ \\
\hline$(\mathrm{cm})$ & $\mathrm{H}_{2} \mathrm{O}$ & $(\%)$ & $\left(\mathrm{g} \mathrm{kg}^{-1}\right)$ & \multicolumn{4}{|c|}{-------- $\left(\mathrm{mg} \mathrm{dm}^{-3}\right)$-------- } & \multicolumn{3}{|c|}{------- $\left(\mathrm{cmol}_{\mathrm{c}} \mathrm{dm}^{-3}\right)^{-------}$} \\
\hline \multirow{5}{*}{$0-20$} & 5.2 & 0.06 & 13.76 & 14 & 5 & 3 & 1.8 & 2.3 & 0.2 & 2.48 \\
\hline & \multicolumn{5}{|c|}{ Micronutrients } & \multicolumn{2}{|c|}{ Sand } & Silt & Clav & Bulk \\
\hline & $\mathrm{B}$ & $\mathrm{Cu}$ & $\mathrm{Fe}$ & $\mathrm{Mn}$ & $\mathrm{Zn}$ & Coarse & Fine & SIII & ulay & density \\
\hline & \multicolumn{5}{|c|}{ - $\left(\mathrm{mg} \mathrm{dm}^{-3}\right)$ - } & \multicolumn{4}{|c|}{ - - } & $\left(\mathrm{g} \mathrm{cm}^{-3}\right)$ \\
\hline & 0.52 & 2 & 168 & 1.9 & 2.9 & 485 & 316 & 19 & 180 & 1.60 \\
\hline
\end{tabular}

(1) Embrapa Amazônia Oriental Soil Analysis Laboratory 
The quantities of fertilizers applied were based on the recommendation per hectare: $170 \mathrm{~kg}$ Nitrogen $(\mathrm{N}), 250 \mathrm{~kg}$ Phosphorus $\left(\mathrm{P}_{2} \mathrm{O}_{5}\right)$ and $250 \mathrm{~kg}$ Potassium $\left(\mathrm{K}_{2} \mathrm{O}\right)$, with all phosphorus applied in the furrow and the " $\mathrm{N}$ " and " $\mathrm{K}$ " in coverage, divided in four applications added to foliar fertilization (15-30-15), with three applications and $0.72 \mathrm{~kg}$ of Borax, equivalent to $2 \mathrm{~g}$ per furrow. Coverage fertilizations were carried out via fertigation with 3 splits of the total dose of nitrogen in the form of calcium nitrate and potassium in the form of potassium nitrate; weeding was done manually during the first 60 days after transplanting (DAT).

Pest and disease monitoring was performed once a week. Bacillus thunringiensis was used for caterpillar control, with two applications in the seedling production stage; Thiamethoxam was used for green aphid control and in the mosaic control; and copper oxychloride was used to combat the diseases: Cercospora spot and Phytophthora blight, with three sprayings performed in the first 60 DAT.

The irrigation system was installed in the week prior to transplanting. In the first 32 days after transplanting, the irrigations were performed homogeneously, with $6.5 \mathrm{~mm}$ applied every two days in all plots of the experimental area, period understood as the adaptation phase of the crop in the field. The $6.5 \mathrm{~mm}$ depth was adopted based on the evapotranspiration range of 3 to $10 \mathrm{~mm}$ for pepper (Marouelli \& Silva, 2008). From this period, the differentiation of the treatments began.

The irrigation system used was the drip irrigation system, composed of a water tank of 5000 liters, installed near the experimental area, a motor/underwater centrifugal pump set (372.86 W), a 32-mm PVC pipe suction and discharge line, a water filter and a pressure regulator.

When leaving the motor pump house, the discharge pipeline was extended to $50-\mathrm{mm}$ blue PVC, $400 \mathrm{kPa}$ nominal pressure (PN40), because, despite the larger diameter, the PN is cheaper in the local market when compared to the cost of the $32-\mathrm{mm}$ diameter blue pipe. The water flow to the plots was carried out through 16-mm diameter polyethylene pipes and distributed to the planting rows by means of a dripping hose, also with $16 \mathrm{~mm}$ in diameter, with drippers spaced $20 \mathrm{~cm}$ apart, totaling 40 drippers per plot, with an average water flow of $2.56 \mathrm{~L} \mathrm{~h}^{-1}$ per emitter at a pressure of $60 \mathrm{kPa}$.

The distribution uniformity coefficient (DUC) was calculated based on the volume collected from the two central drippers of each plot, totaling 40 collections. Using Equation 1, we obtained $97.46 \%$ DUC with $1.561 \mathrm{~L} \mathrm{~h}^{-1}$ of average flow per dripper.

DUC $=\frac{\mathrm{q}_{25}}{\mathrm{q}_{\mathrm{m}}} \times 100$

In which:

DUC - Distribution Uniformity Coefficient, (\%); $\mathrm{q}_{25}$ - average of $25 \%$ of the flows with lower values $\left(L h^{-1}\right)$; and $q_{m}-$ average of all flows $\left(L h^{-1}\right)$.
The water depth based on each one of treatment was applied with a two-day irrigation frequency, If rainfall occurred during the irrigation interval, the evaporated depth was considered as the difference between the previous reading and the current reading, being calculated according to Equation 2 , and the application irrigation time according to Equation 3.

$\mathrm{ID}=\frac{\mathrm{ECA} \times \mathrm{T}}{\mathrm{Ea}}$

In which:

ID - irrigation depth to be applied in each treatment (mm); ECA - two days of accumulated Class-A pan evaporation $(\mathrm{mm})$; $\mathrm{T}$ - treatment percentage $(0.3 ; 0.6$; 0.9 ; 1.2 and 1.5); and Ea - efficiency of the irrigation system (0.95).

$\mathrm{It}=\frac{\mathrm{ID} \times A}{\mathrm{q}_{\mathrm{m}} \times \mathrm{n}_{\mathrm{p}}}$

In which:

It - irrigation time (h); A - area occupied per plant $\left(\mathrm{m}^{2}\right)$; $\mathrm{q}_{\mathrm{m}}$ - average dripper flow $\left(1.561 \mathrm{~L} \mathrm{~h}^{-1}\right)$; and $\mathrm{n}_{\mathrm{p}}$ - number of drippers per plant (4).

The harvest was carried out in three stages, at 75,100 and 120 DAT, with the last harvest occurring on January 16, 2015, culminating with the end of the field phase. The time of harvesting was determined when most of the plants showed some fruits with orange coloration.

The variables analyzed were fruit yield $\left(t \mathrm{ha}^{-1}\right)$, number of fruits per plant (fruit plant ${ }^{-1}$ ), fruit dry mass per $100 \mathrm{~g}$ of fruit fresh mass $\left(\mathrm{g} 100 \mathrm{~g}^{-1}\right.$ - FDM), fruit diameter - FD (mm), fruit length - FL $(\mathrm{mm})$, plant height - PH (cm) and water use efficiency - WUE $\left(\mathrm{kg} \mathrm{ha}^{-1} \mathrm{~mm}^{-1}\right)$. The latter according to Equation 4.

WUE $=\frac{\text { Yield }}{\text { TWD }}$

In which:

Yield - Fruit yield (kg ha-1);

TWD - Total water depht (mm)

Plant height measurements were performed with a measuring tape, while the fruit height measurements were performed with a pachymeter. The collected data were submitted to F-test; when there was significant variation, linear and quadratic regression analyses were applied at the significance level of $1 \%$ and $5 \%$, with the assistance of the software Assistat 7.7 .

\section{Results and discussion}

During the field experiment, the maximum temperatures ranged from $28.1^{\circ} \mathrm{C}$ to $35.5^{\circ} \mathrm{C}$, the minimum temperatures were between $20.4^{\circ} \mathrm{C}$ and $24.1^{\circ} \mathrm{C}$ and the mean was $27.9^{\circ} \mathrm{C}$. These values corroborate those identified by Pinto et al. (2006), which indicate the range of $21^{\circ} \mathrm{C}$ to $35^{\circ} \mathrm{C}$ as satisfactory for the development of the pepper. While the mean relative air humidity was $74.40 \%$, the maximum relative 
humidity ranged from $94.0 \%$ to $98.0 \%$. During the period of the experiment, $133.2 \mathrm{~mm}$ of rainfall and $518 \mathrm{~mm}$ of ECA were recorded, with an average of
$5.82 \mathrm{~mm}$, which provided a water deficit, with the months of October and November (25 DAT and 75 DAT), the most critical, with $232.20 \mathrm{~mm}$ (Figure 1).

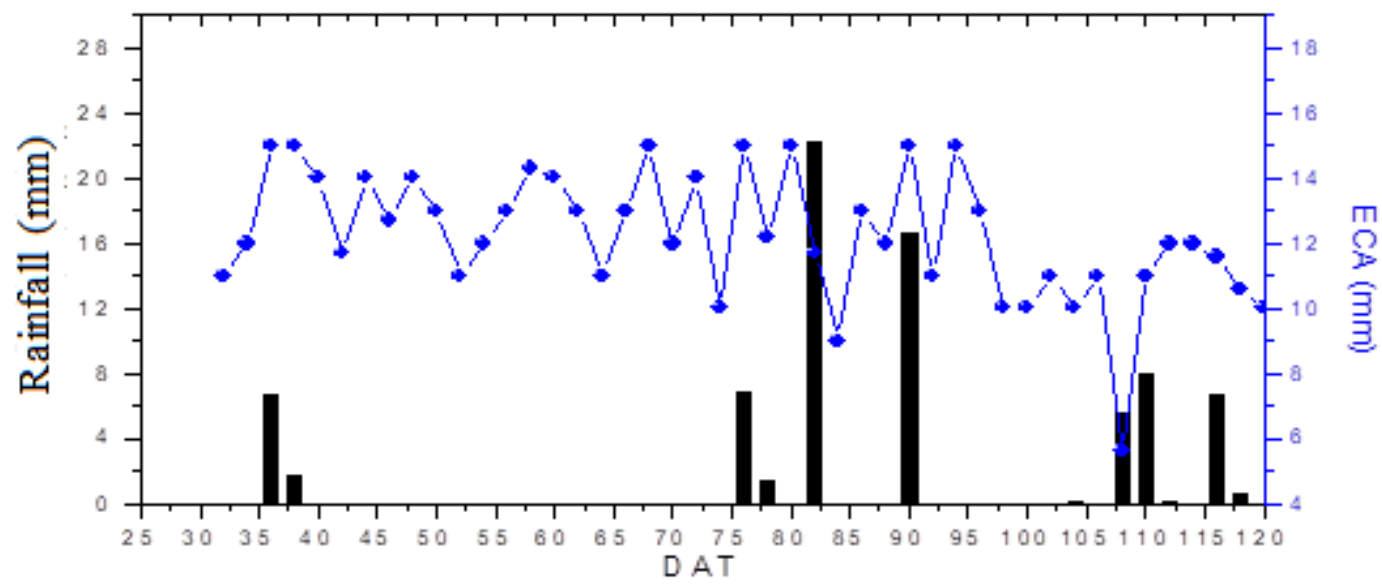

Figure 1 - Rainfall and two days of accumulated Class "A" pan evaporation (ECA) during the period of the treatments application (DAT - days after transplanting).

The values of the total irrigation depths applied in the treatments T90, T120 and T150 are within the range of 500 to $1000 \mathrm{~mm}$ (Table 2), considered to be optimal for the development and productivity of pepper (Marouelli \& Silva, 2008). These authors also state that the daily requirement of pepper is based on the crop evapotranspiration, which can vary from $3 \mathrm{~mm}$ to $10 \mathrm{~mm}$, at the peak of higher crop demand.

In the analysis of variance, it was observed that the factors responded significantly at $1 \%$ probability to the effect of the irrigation depth, except for fruit diameter (FD) $(p<0.05)$. It was also observed that the average number of fruits per plant - ANFP and plant height - $\mathrm{PH}$ showed differences between the blocks $(p<0.05)$ (Table 3$)$. In addition, it can be observed that the variation of the environment between the blocks in the same treatment was not able to significantly influence the physiological development of the crop for the analyzed variables.

Table 2 - Application demonstration of the irrigation depths during the field cultivation stage of the Capsicum chinense Jacq cv. Lupita.

\begin{tabular}{|c|c|c|c|c|c|}
\hline Application demonstration & & & reatmen & & \\
\hline of the irrigation & T30 & T60 & T90 & T120 & T150 \\
\hline Number of Irrigation & 43 & 43 & 43 & 43 & 43 \\
\hline Initial irrigation depth (mm) & 47.40 & 47.40 & 47.40 & 47.40 & 47.40 \\
\hline Rainfall (mm) & 133.20 & 133.20 & 133.20 & 133.20 & 133.20 \\
\hline Irrigation depth/treatment (mm) & 155.4 & 310.8 & 466.2 & 621,6 & 777.0 \\
\hline Initial time of irrigation $(\mathrm{h})$ & 7.29 & 7.29 & 7.29 & 7.29 & 7.29 \\
\hline Average time by irrigation $(\mathrm{h})$ & 0.52 & 0.92 & 1.31 & 1.71 & 2.11 \\
\hline Average irrigation depth $\left(\mathrm{mm} \mathrm{dia}^{-1}\right)$ & 2.79 & 4.08 & 5.38 & 6.67 & 7.96 \\
\hline Irrigation time/treatment $(\mathrm{h})$ & 23.89 & 47.78 & 71.67 & 95.56 & 20.47 \\
\hline Total water depth $(\mathrm{mm})$ & 336.00 & 491.40 & 646.80 & 802.20 & 957.60 \\
\hline Total irrigation time $(\mathrm{h})$ & 31.13 & 54.98 & 78.82 & 102.67 & 126.52 \\
\hline
\end{tabular}

Table 3 -Variance analysis of the plant height $(\mathrm{PH})$, fruit length ( $F L)$, fruit weight $(F W)$, fruit diameter (FD), fruit dry mass (FDM), water use efficiency (WUE), fruit yield (Yield) and number of fruits per plant (NFP).

\begin{tabular}{|c|c|c|c|c|c|c|c|c|c|}
\hline \multirow{2}{*}{\multicolumn{2}{|c|}{ Variation Factor }} & \multicolumn{8}{|c|}{ Mean Square } \\
\hline & & $\begin{array}{l}\mathrm{PH} \\
(\mathrm{cm})\end{array}$ & $\begin{array}{c}\mathrm{FL} \\
(\mathrm{mm})\end{array}$ & $\begin{array}{l}\text { FW } \\
(\mathrm{g})\end{array}$ & $\begin{array}{l}\text { FD } \\
(\mathrm{mm})\end{array}$ & $\begin{array}{c}\text { FDM } \\
\left(g_{\left.100 g^{-1}\right)}\right.\end{array}$ & $\begin{array}{c}\text { WUE } \\
\left(\mathrm{kg} \mathrm{m}^{-3}\right)\end{array}$ & $\begin{array}{c}\text { Yield } \\
\left(\mathrm{kg} \mathrm{ha}^{-1}\right)\end{array}$ & $\begin{array}{c}\text { NFP } \\
\text { (fruit plant }\end{array}$ \\
\hline Treatment & 4 & $66.31^{* *}$ & $42.18^{\star *}$ & $1.94^{* *}$ & $3.67^{*}$ & $17.66^{* *}$ & $2.56^{* \star}$ & $28485620.54^{* *}$ & $9803.13^{* *}$ \\
\hline Blocks & 3 & $2.82^{*}$ & $0.89 n s$ & $0.24 \mathrm{~ns}$ & $1.41 \mathrm{~ns}$ & $0.94 \mathrm{~ns}$ & $0.10 \mathrm{~ns}$ & $9380556.80 \mathrm{~ns}$ & $2105.93^{*}$ \\
\hline Residue & 12 & 3.59 & 4.48 & 0.10 & 0.79 & 1.89 & 0.06 & 4501074.66 & 585.23 \\
\hline Average & - & 41.72 & 43.29 & 5.59 & 23.12 & 11.74 & 2.30 & - & \\
\hline CV (\%) & - & 4.44 & 4.89 & 6.25 & 3.84 & 11.73 & 10.96 & 18.20 & 12.63 \\
\hline
\end{tabular}

**, *: significant at $1 \%$ and $5 \%$ probability by $\mathrm{F}$ test; respectively; ns: not significant at $5 \%$ of probability by $\mathrm{F}$ test. 
The results of fruit yield as a function of treatments showed behavior according to a quadratic model (Figure 2a), as well as the number of fruits per plant - NFP (Figure 2b), fruit dry mass FDM (Figure 2c), plant height - PH (Figure 2d), fruit length - FL (Figure 3a), fruit weight - FW (Figure 3b), and fruit diameter - FD (Figure 3c). It was observed an increase of this variables to an optimum point, representing the ideal irrigation depth for maximum production, from which a decrease occurs.
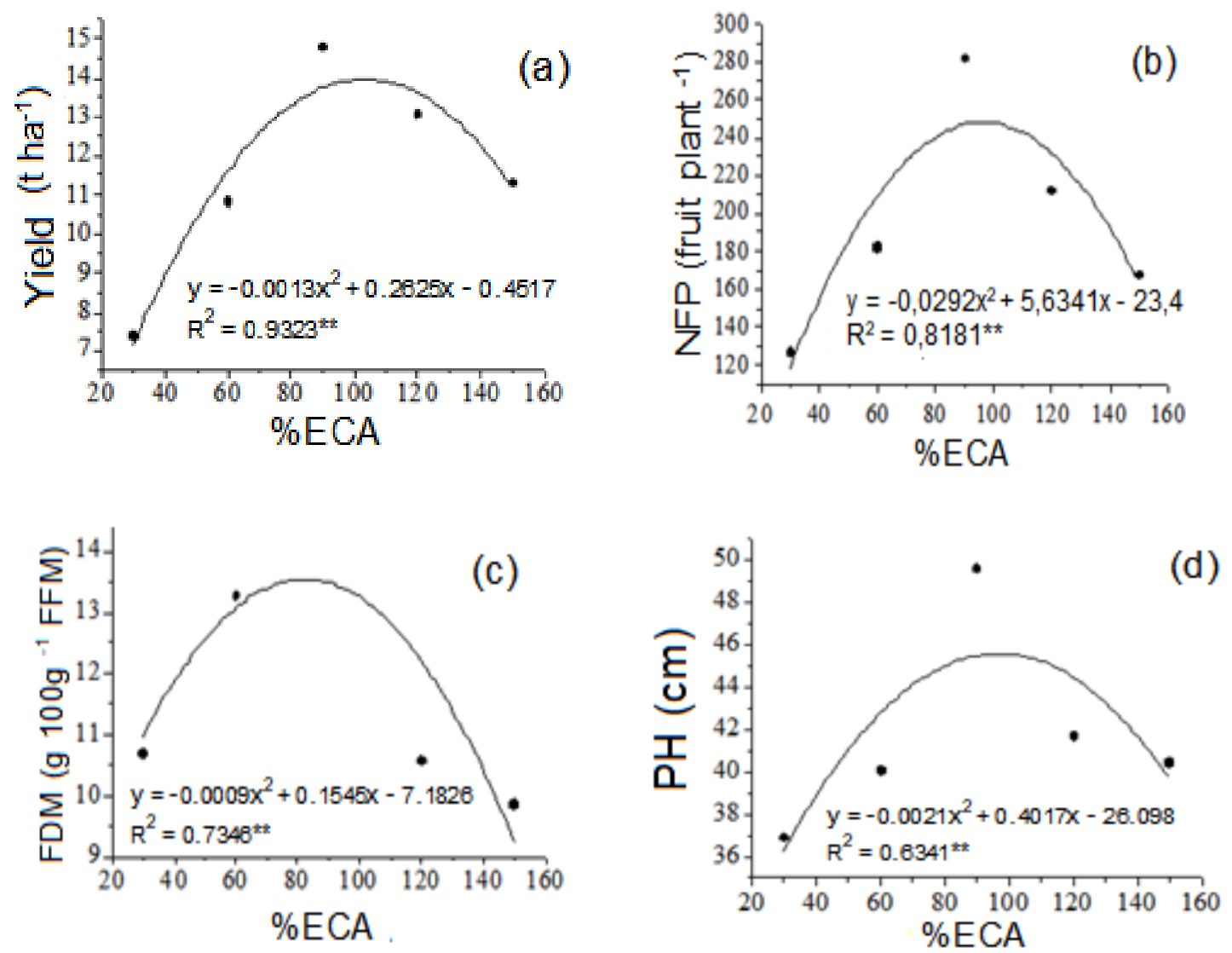

Figure 2 - Variables response to increasing irrigation depths: (a) Yield - fruit yield; (b) NFP - number of fruits per plant; (c) FDM - fruit dry mass per $100 \mathrm{~g}$ of fruit fresh mass (FFM); (d) PH - plant height.

${ }^{* *}$ significant at $1 \%$ probability.

Maximum fruit yield was achieved with a depth of $101 \%$ ECA $\left(14 \mathrm{t} \mathrm{ha}^{-1}\right)$, NFP at $96.47 \%$ (248 fruit plant

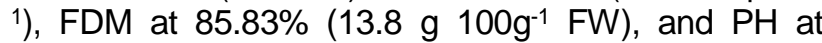
95.64\% (45.30 cm). Marinho (2011), when working with the production of pepper $\mathrm{cv}$. Tabasco under different soil water stresses in a protected environment, observed that the crop responded to the applied water variations $(p<0.01)$. This author also adds that the water deficit, when provided in the vegetative phase, can cause a moderate to severe water stress. This can also be seen in Lima et al. (2013), with the cultivar Cayenne in the conditions of the climate type Cwa. Significant reduction in yield could also be observed by Guang-Cheng et al. (2010), when working with Zao feng pepper under water deficit.

Azevedo et al. (2005), who worked with pepper cv. Tabasco in the edaphoclimatic conditions of Pentecoste-CE, identified that the depth of $120 \%$ ECA provided the highest absolute value for number of fruits per plant and yield. Albuquerque et al. (2011) also identified that with $102 \%$ ETc depth, higher yield and absolute value of fruits were obtained with the pepper crop in Recife-PE. This is also confirmed by Aragão et al. (2012), who showed an increase in yield and number of fruits as a function of the increase in the water depth for the same crop. These results are similar to those obtained in this work.

Borroca et al. (2014) and Albuquerque et al. (2011) found that the pepper crop, under hot and humid climate, reached maximum yield $\left(17.70 \mathrm{t} \mathrm{ha}^{-1}\right)$ at $113.6 \%$ ETo. These results, like those of the present study, demonstrate that it is necessary to apply a water depth greater than $100 \%$ ECA to obtain a higher yield.

In relation to plant height, Lima et al. (2012), working with the pepper crop, found that maximum plant height can be reached at $125 \%$ of the crop evapotranspiration (ETc) replacement, responding quadratically to the different depths. Behavior similar to that identified in this work, with height data within the range identified by Smith \& Heiser (1957), from 45 to $76 \mathrm{~cm}$ for Capsicum chinense.

This variation can be related to different irriga- 
tion depths; as an example, Marinho (2011) observed that the height of plants of the $\mathrm{cv}$. Tabasco varied by $14 \%$ between the lowest and the highest irrigation depth imposed at 116 DAT. Rezende et al. (2002) also show that plant height is influenced by the volume of water applied.

The maximum points estimated for FL (Figure
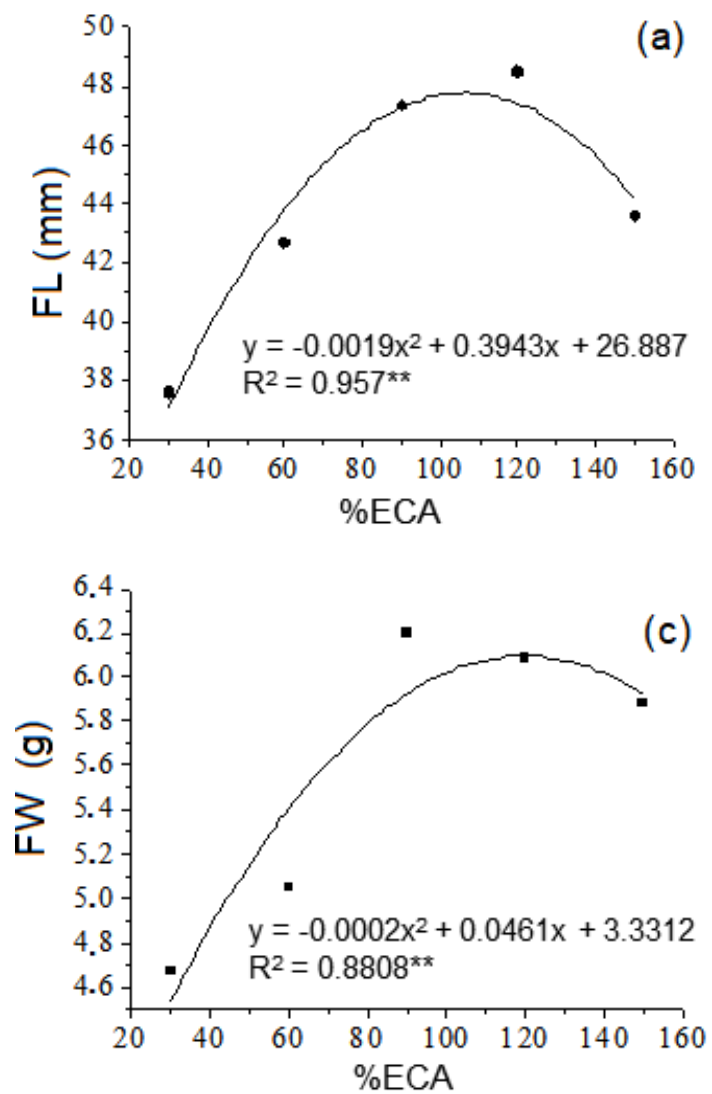

3a) were at $103.76 \%(47.34 \mathrm{~mm})$, FD (Figure 3b) at $123.50 \%(23.98 \mathrm{~mm}$ ) and FW (Figure 3c) $115.25 \%$ $(5.98 \mathrm{~g})$. The length of fruits of the cv. Lupita was superior to that indicated by the seed supplier $(35 \mathrm{~mm})$, and similar in value to fruit diameter. Borroca et al. (2014) verified that the best responses for length and diameter of pepper occurred with $120 \%$ ETo depth $(624.96 \mathrm{~mm})$.
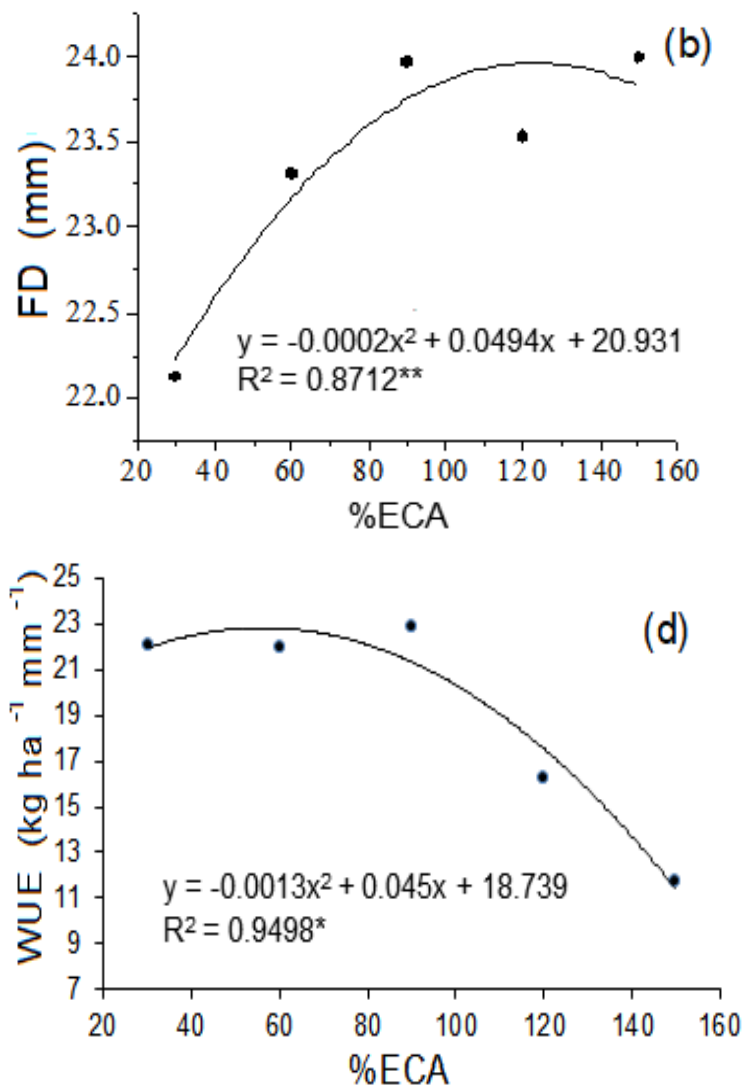

Figure 3 - Variables response to increasing irrigation depths: (a) FL - fruit length; (b) FD - fruit diameter; (c) FW - fruit weight; (d) WUE - water use efficiency.

${ }^{* *}$ - significant at $1 \%$ probability; ${ }^{*}$ - significant at $5 \%$ probability.

The fruit weight behavior verified in this experiment as a function of the different treatments can be correlated with Lima et al. (2012), who worked with sweet pepper under different soil water stresses, and Azevedo et al. (2005), with pepper cv. Tabasco, with different percentages of ECA, obtaining an increase in fruit weight as the percentages of the irrigation depths increased. This response to fruit weight in T150 can be explained by soil nutrient loss, which probably resulted in a reduction in fruit wall thickness, number of seeds per fruit, length and diameter of the fruit.

The water use efficiency (WUE) reached a maximum of $56 \%$ ECA $\left(22.78 \mathrm{~kg} \mathrm{ha}^{-1} \mathrm{~mm}^{-1}\right)$ and had $11.24 \mathrm{~kg} \mathrm{ha}^{-1} \mathrm{~mm}^{-1}$ as the lowest value, at $150 \%$ ECA, respectively. The parameter expresses the relationship between the yield and total water depth, and thus indicates the amount of water in which the physiological activities of the crop is related to the increase in cell volume and plant growth, in addition to nutrient absorption. This also serves as a parameter of water use with greater environmental awareness. Similar results were obtained by Lima et al. (2013), who worked with Pepper cv. Cayene under different soil water stresses, and Azevedo et al. (2005), who worked with Tabasco pepper, obtaining the highest water use efficiency value of $1.85 \mathrm{~kg} \mathrm{~m}^{-3}$, with a $60 \%$ evaporation depth in the class 'A' pan.

Ati et al. (2012) state that water is one of the most important compounds in an active plant, constituting more than $80 \%$ of the growing tissue. Based on the response data to the applied treatments, when the water availability in the radicular environment was restricted, treatments T30 and T60, the activation of the plant defense mechanism may have occurred, providing the reduction of stomatal opening and, consequently, loss of cellular turgescence (Guimarães et al., 2011). 


\section{Conclusions}

Maximum fruit yield is achieved with the irrigation depth corresponding to about $100 \%$ of the evaporation of the Class 'A' pan.

The water use efficiency reaches the maximum value with the replacement factor of $56 \%$ of the evaporation of the Class ' $A$ ' pan, but with low productivity. Therefore, the percentage of $101 \%$ ECA was more promising.

\section{Acknowledgements}

To FAPEMIG - Foundation for Research Support of the State of Minas Gerais, for granting the scholarship; to CNPq - National Council for Research and Scientific and Technological Development, for granting the scholarships for scientific initiation and research production; and to the Federal Rural University of Amazonia, for the financial support to the publication of this manuscript.

\section{References}

Albuquerque FS, Silva EFF, Albuquerque Filho JAC, Nunes MFFN (2011) Crescimento e rendimento de pimentão fertirrigado sob diferentes lâminas de irrigação e doses de potássio. Engenharia Agrícola e Ambiental 15(7):686-694.

Ati AS, lyada AD, Najim SM (2012) Water use efficiency of potato (Solanum tuberosum L.) under defferent irrigation methods and potassium fertilizer rates. Annals of Agricultural Science 57(2):99-103.

Azevedo BMD, Chaves SWP, Medeiros JF, Aquino BF, Bezerra FML, Viana TVA (2005) Rendimento da pimenteira em função de lâminas de irrigação. Ciência Agronômica 36(3):268-273.

Ayas S, Orta H, Yazgan S (2011) Deficit irrigation effects on brocolli (Brassica oleracea $L$. var. monet) yield in unheated greenhouse condition. Bulgarian Journal of Agricultural Science 17(4):551-559.

Aragão VF, Fernandes PD, Gomes Filho RR, Carvalho CM, Feitosa HO, Feitosa EO (2012) Produção eficiente no uso da água do pimentão submetido a diferentes lâminas de irrigação e níveis de nitrogênio. Revista Brasileira de Agricultura Irrigada 6(3):207-216.

Borroca MV, Bonomo R, Souza JM, Fernandes AA (2014) Produção de pimenta "dedo-de-moça" e de "cheiro" em função de lâminas de irrigação no norte capixaba. In: II INOVAGRI Internacional Meeting, INOVAGRI. Fortaleza, Brasil.

Biblico C, Carvalho JÁ, Martins M, Rezende FC, Freitas EA, Gomes LAA (2010) Desenvolvimento vegetativo e produtivo da berinjela submetida a diferentes tensões de água no solo. Revista Brasileira de Engenharia Agrícola e Ambiental 14(7):730-735.
Doorenbos J, Kassam AH (2000) Efeito da água no rendimento das culturas. Campina Grande: Tradução Gheyi HR et al., UFPb/FAO. 221p.

Esteves BDS, Mendonça JC, Sousa EF, Bernardo S (2010) Avaliação do Kt para estimativa da evapotranspiração de referência (ETo) em Campos dos Goytacazes, RJ. Revista Brasileira de Engenharia Agrícola e Ambiental 14(3):274-278.

Guang-cheng S, Na L, Zhan-yu Z, Shuang-en Y, Chang-ren C (2010) Growth, yeld and water use efficiency response of greenhouse-grow hot pepper under time-space deficit irrigation. Scientia Horticulturae 126(2):172-179.

Guimarães CM, Stone LF, Oliveira JP, Rangel PHN, Rodrigues CAP (2011) Sistema radicular do arroz de terras altas sob deficiência hídrica. Pesquisa Agropecuária Tropical 41(1):126-134.

Lima EMC, Matiolli W, Thebaldi MS, Rezende FC, Faria MA (2012) Produção de pimentão cultivado em ambiente protegido e submetido a diferentes lâminas de irrigação. Agrotecnologia 3(1):40-56.

Lima EMC, Carvalho JA, Rezende FC, Thebaldi MS, Gatto RF (2013) Rendimento da pimenta cayenne em função de diferentes tensões de água no solo. Engenharia Agrícola e ambiental 17(11)1181-1117.

Marinho LB (2011) Irrigação plena e com déficit em pimenta cv. Tabasco em ambiente protegido. Unesp (Tese de doutorado em Ciências).

Moura AP, Filho MM, Guimarães JA, Amaro GB, Liz RS (2013) Manejo integrado de pragas de pimentas do gênero Capsicum. Brasília, DF.

Marouelli WA, Silva HR (2008) Irrigação. In: Ribeiro CSDC. Pimentas Capsicum. Brasília: Embrapa Hortaliças. p.95-108.

Oliveira EC, Carvalho JA, Rezende FC, Freitas WA (2011) Viabilidade técnica e econômica da produção de ervilha (Pisum sativum L.) cultivada sob diferentes lâminas de irrigação. Engenharia Agrícola 31(2):324333.

Pinto MF, Puiatti M, Caliman FRB, Moreira GR, Mattos RN (2006) Clima, época de semeadura, produção de mudas, plantio e espaçamento da cultura da pimenteira. Informe Agropecuário. Belo Horizonte.

Qiu R, Kang S, Li F, Du T, Tong L, Wang F, Chen R, Liu J, Li S (2011) Energy partitioning and evapotranspiration of hot pepper grown e greenhouse with furrow and drip irrigation methods. Scientia Horticulturae 129 (4):790-797.

Reifschneider FJB, Ribeiro CSD (2008) Cultivo. In: Ribeiro CSDC. Pimentas Capsicum. Brasília: Embrapa Hortaliças. p.11-14. 
Rezende FC, Frizzone JA, Pereira AS, Botrel TA (2002) Plantas cultivadas em ambiente protegido com $\mathrm{CO}_{2}$. II. Produção de matéria seca. Acta Scientiarum, v.24(5):1527-1533.

Ribeiro PAA, Coelho RD, Teixeira MB (2010) Entupimento de tubos de gotejadores convencionais com aplicação de Cloreto de Potássio (branco e vermelho) via duas qualidades da água. Engenharia Agrícola 30(2):279-287.

Smith PG, Heiser CB (1957) Taxonomy of Capsicum chinense Jacq. and the geographic distribuition the cultivated Capsicum species. Bulletin of the Torrey Botanical Club. p.413-420.
Sousa AS, Sousa JRA. Balanço hídrico no estado do Pará. Pará Rural: o veículo do agronegócio paraense, Belém, v. 2, n. 3, 2011.

Souza RORM, Pantoja AV, Amaral MCM, Neto JAP (2012) Cenário da agricultura irrigada do Estado do Pará. Irriga 17(2):177-188.

Souza CMA, Freitas FS, Carvalho CJR, Vasconcelos SS, Kato OR (2011) Atributos físicos do solo em sistemas agroflorestais sequenciais no município de Igarapé Açu, Pará. In: Congresso Brasileiro de Sistemas Agroflorestais. Belém, Brasil.

Yaghi T, Arslan A, Naoum F (2013) Cucumber (Cucumis sativus, L.) water use efficiency (WUE) under plastic mulch and drip irrigation. Agricultural Water Management 128:149-157. 